ORİJINAL MAKALE / ORIGINAL ARTICLE

Balıkesir Sağlık Bilimleri Dergisi / BAUN Sağ Bil Derg

Balıkesir Health Sciences Journal / BAUN Health Sci J

ISSN: 2146-9601- e ISSN: 2147-2238

Doi: https://doi.org/10.53424/balikesirsbd.940627

\title{
Histerektomi Ameliyatı Geçiren Kadınlarda Kaygı, Ağrı ve Sosyal Desteğin Derlenme Kalitesine Etkisi
}

\section{Ebru BURMA國, Oya KAVLAK 國 2}

${ }^{1}$ Malatya Eğitim ve Araştırma Hastanesi

${ }^{2}$ Ege Üniversitesi, Hemşirelik Fakültesi, Kadın Sağlı̆̆ı ve Hastalıkları Hemşireliği AD

"Histerektomi Ameliyatı Geçiren Kadınlarda Kaygı, A ̆grı ve Sosyal Desteğin Derlenme Kalitesine Etkisi” adlı yüksek lisans tezinden türetilmiştir.

Geliş Tarihi / Received: 21.05.2021, Kabul Tarihi / Accepted: 13.09.2021

\section{ÖZ}

Amaç: Histerektomi ameliyatı sonrası derlenme kalitesinin arttırılması hasta ve bakım verenler tarafından önemlidir. Bu bağlamda hastanın derlenme kalitesini etkileyen unsurların değerlendirilmesi gerekmektedir. Araştırmanın amacı histerektomi ameliyatı geçiren kadınlarda kaygı, ağrı ve sosyal desteğin derlenme kalitesi üzerindeki etkisinin incelenmesidir. Gereç ve Yöntem: Araştırmaya Mart 2019 - Ekim 2019 tarihleri arasında bir Üniversitenin Eğitim ve Araştırma Hastanesi Kadın Hastalıkları ve Doğum Kliniklerinde histerektomi ameliyatı olan 150 kadın dahil edilmiştir. Hastalara Birey Tanılama Formu, Spielberger Durumluk-Sürekli Kaygı Envanteri, Görsel Kıyaslama Ölçeği, Algılanan Sosyal Destek Ölçeği ve Derlenme Kalitesi Anketi’nden oluşan veri toplama araçları uygulanmıştır. Veriler yüz yüze görüşme tekniği ile histerektomi ameliyatından sonra 24 . saatte toplanmıştır. Elde edilen veriler SPSS ile analiz edilmiştir. Veri analizinde betimleyici istatistikler ile birlikte korelasyon ve regresyon analizleri kullanılmıştır. Sonuçlar $\mathrm{p}<0.05$ anlamlılık düzeyinde değerlendirilmiştir. Bulgular: Histerektomi olan kadınların yaş ortalaması 55.13 \pm 11.62 olup, \%67.3'ü ilköğretim mezunu olup, \%49.3'ü bening jinekolojik hastalıklar, \%14.7'si pelvik taban bozuklukları nedeniyle ameliyat olmuştur. Histerektomi ameliyatı olan kadınlarda derlenme kalitesi puan ortalamaları ile durumluk kaygı arasında negatif yönlü $(\mathrm{r}=-0.434, \mathrm{p}<0.01)$; sürekli kaygı arasında negatif yönlü $(-0.413, \mathrm{p}<0.01)$; ağr1 şiddeti ile negatif yönlü $(\mathrm{r}=-0.499, \mathrm{p}<0.01)$ ve sosyal destek algısı ile pozitif yönlü ilişki olduğu $(\mathrm{r}=0.188, \mathrm{p}<0.05)$ bulunmuştur. Sonuç: Histerektomi uygulanan kadınlarda durumluk kaygı, sürekli kaygı ve ağrı şiddeti derlenme kalitesini olumsuz etkilerken, sosyal destek derlenme kalitesini olumlu yönde etkilemektedir.

Anahtar Kelimeler: Histerektomi, Kayg1, Ağrı, Sosyal Destek, Derlenme Kalitesi.

\section{The Effect of Anxiety, Pain and Social Support on Recovery Quality in Women Undergoing Hysterectomy}

\section{ABSTRACT}

Objective: Postoperative recovery quality is important for patients and caregivers in hysterectomy. In this context, factors affecting the recovery quality of the patient should be evaluated. The aim of this study was to determine the effect of anxiety, pain and social support on recovery quality in women undergoing hysterectomy. Materials and Methods: The study included 150 women who had a hysterectomy in the Gynecology and Obstetrics Clinics of the University Training and Research Hospital between March 2019 and October 2019. Data collection tool consisting of Individual Identification Form, State Trait Anxiety Inventory, Visual Analog Scale, Perceived Social Support Scale and Recovery Quality Questionnaire were administered to the patients. Data were collected by face to face technique at 24 hours after hysterectomy surgery. The data were analyzed by SPSS. Descriptive statistics, correlation and regression were used in the data analysis. The results were evaluated as $\mathrm{p}<0.05$. Results: The mean age of the women who had hysterectomy was $55.13 \pm 11.62,67.3 \%$ of them were primary school graduates, $49.3 \%$ were operated for benign gynecological diseases and $14.7 \%$ for pelvic floor disorders. There was a negative correlation between the mean recovery quality score and state anxiety $(\mathrm{r}=-0.434, \mathrm{p}<0.01)$, trait anxiety $(-0.413, \mathrm{p}<0.01)$ and with pain severity $(\mathrm{r}=-0.499$, $\mathrm{p}<0.01$ ), and it was found that a positive relationship with perception of social support and recovery quality score ( $\mathrm{r}=0.188$, $\mathrm{p}<0.05)$ in women who had hysterectomy surgery. Conclusion: State anxiety and trait anxiety as well as pain severity adversely affect recovery quality in women undergoing hysterectomy, while social support positively affects patient recovery quality.

Keywords: Hysterectomy, Anxiety, Pain, Social Support, Recovery Quality.

Sorumlu Yazar / Corresponding Author: Oya KAVLAK, Ege Üniversitesi, Hemşirelik Fakültesi, Kadın Sağlı̆̆ı ve Hastalıkları Hemşireliği AD, İzmir/TÜRKIYE

E-mail: oya.kavlak@ege.edu.tr

Bu makaleye atıf yapmak için / Cite this article: Burma, E., \& Kavlak, O. (2021). Histerektomi ameliyatı geçiren kadınlarda kayg1, ağrı ve sosyal desteğin derlenme kalitesine etkisi. Balıkesir Sağlık Bilimleri Dergisi, 10(3):325-333. https://doi.org/10.53424/balikesirsbd.940627

CCopyright 2021 by the Balıkesir Sağlık Bilimleri Dergisi. 


\section{GíRIŞ}

Genelde 30-50 yaşları arasındaki kadınlara uygulanan histerektomi ameliyatı, uterusun cerrahi müdahaleyle çıkarılmasıdır ve günümüzde pelvik cerrahi operasyonları arasında en fazla uygulanan tedavi yöntemlerinden biridir (Wilson, Pandeya, Byles ve Mishra, 2019). Gelișmiş ülkelerde histerektomi insidansı yüksek olup Amerika Birleşik Devletleri'nde her y1l ortalama 600.000 kadin histerektomi ameliyat1 olmaktadır (Agrawal ve ark., 2018). Danimarka (173) ve Almanya (295) dahil olmak üzere birçok Avrupa ülkesinde bu oran daha düşük olarak bildirilmektedir (Hammer ve ark., 2015). Derlenme, anestezi ya da ameliyatın bitiminden sonra, hastanın havayolu reflekslerini tam anlamıla geri kazanması sürecidir. $\mathrm{Bu}$ sürede hasta, derlenme ünitesinde takip edilmektedir. $\mathrm{Bu}$ ünitelerde gerekli malzemeler ve görevliler bulunmakta, ameliyatın ardından hastalarda oluşan komplikasyonlar yönetilmektedir. Derlenme ünitelerinde kalış süreci, hastanın iyilik durumuna ve ameliyat süresine göre değişim göstermektedir (Preston ve Gregory, 2015). Hastanede yatma süreci, uyanma zamanı, kafa karışıklığı, kusma veya ağrı gibi durumlar birçok hastanın endişelenmesine ve ameliyat sonrası iyileşme süreciyle ilgili olumsuzluklar yaşanmasına yol açmaktadır. Derlenmenin kötü bir niteliğe sahip olması yatış süresini uzatmakta ve kaynak kullanımı konusunda olumsuz sonuçlara yol açmaktadır (Myles, Weitkamp, Jones, Melick ve Hensen, 2000). Ameliyattan önce hastanın kaygı yaşaması, ameliyat sırasında hasta üzerinde daha fazla anestezi uygulanmasına, ameliyattan sonra yaşanan ağrının ve dolayısıyla analjezik ihtiyacının artmasına, solunum sistemi problemleri, taşikardi, yorgunluk, kusma, bulantı gibi daha fazla komplikasyon yaşanmasına, hastanede kalış süresinin uzamasına yol açmakta, bu da hasta memnuniyetini, iyileşmeyi ve yaşam kalitesini negatif bir şekilde etkilemektedir (Bailey, 2010, Stamenkovic ve ark., 2018). Yapılan çalışmalarda ameliyat öncesi kaygının ameliyat sonrası ağrı yoğunluğunu arttırdığı dolayısıyla daha fazla analjezi gereksinimine ihtiyaç duyulduğu belirtilmektedir (Dunn ve ark., 2017, Ocalan ve ark., 2015, Raichle ve ark., 2015, Stamenkovic ve ark., 2018). Scheel ve arkadaşları (2017) tarafından histerektomi ameliyatı olan kadınlarda ağrının psikolojik belirleyicilerin incelendiği çalışmada ağrı kaygısının ve ağrıya özgü psikolojik değişkenlerin ameliyat sonrası ağrının en önemli yordayıcısı olduğu belirlenmiştir. Benzer şekilde Pinto ve arkadaşları (2018) tarafından psikolojik faktörlerin histerektomi sonrası ağriya etkilerini inceledikleri prospektif kohort çalışmasında ameliyat öncesi ağrı, duygusal durum ve kaygının ameliyat sonrası ağrının ön belirleyicileri olduğu saptanmıştır. Hastalara yapılan herhangi bir cerrahi müdahale hastada ağrı, ölüm korkusu, sakatlık, sevdiği kişi ve aktivitelerden uzak kalma ve beden imajının değişmesi gibi korku ve kaygıların yaşanmasına neden olmaktadır (Güler ve Taşkın, 2001; Özbayır 2002). Birçok kadın için uterus üremenin bir sembolü olarak görülmekte, histerektomi ameliyatı da kadınlarda korku ve kaygının yanı sıra cinsel fonksiyonun, doğurganlık yeteneğinin ve kadınlık rolünün kaybedilmesi, eş ile ilişkilerinin bozulması, menopoz semptomlarının yaşanması ve fiziksel gücün kaybedeceği düşüncesi gibi kaygıların da yaşanmasına neden olmaktadır (Erdoğan ve ark., 2020; Güler ve Taşkın, 2001). Histerektomi ameliyatından sonra ortaya çıkan psikolojik tepkilerin ameliyattan sonra birçok fizyolojik ve psikolojik komplikasyon yaşanmasına neden olabileceği bilinmektedir (Ramdhan ve ark., 2017). Histerektomi uygulanan hastalar ile yapılan çalışmalar incelendiğinde hastaların genel olarak postoperatif dönemde yüksek kaygıya sahip olduğu belirtilmektedir. Özdemir (2008) tarafindan histerektomi sonrasında yaşama yönelik verilen eğitim ve gevşeme egzersizlerinin kaygı düzeyine etkisinin araştırıldığ de sürekli kaygı düzeyleri yüksek bulunmuştur. Benzer şekilde Avcı (2015) tarafindan histerektomi uygulanan hastalarda kadınların yüksek düzeyde durumluk kaygıya sahip olduğu tespit edilmiştir. Ergen ve arkadaşları (2019) tarafından yapılan bir diğer çalışmada da total abdominal histerektomi uygulanan kadınların durumluk kaygı düzeyleri yüksek bulunmuştur. Sağlık üstündeki olumlu etkileri sayesinde sosyal destek, hemşireler açısından oldukça önemlidir. Çağdaş hemşirelik mesleğinin kurucusu Florence Nightingale, hemşirelerin hastalara ve ailelere verdiği desteğin önemli olduğunu vurgulamış, ardından hemşirelik bakımı kapsamına sosyal destek de alınmış ve hemşirelik girişimlerinin en önemli işlevlerinden biri haline gelmiştir (Peterson, 2000). Strese yol açan durumlarla mücadele ederken kişinin algıladığı sosyal destek önemli bir yere sahiptir. Diğer taraftan kişinin yaşamı zorlayıcı yönleriyle başa çıkmasında ve stresin olumsuz etkilerine direnç göstermesinde başkalarıyla olan sosyal ilişkilerin önemli rol oynadığı düşünülmektedir. Zor durumda ya da sıkıntı içinde olan bireye aile üyelerinin, akrabalarının, arkadaşlarının yanı sıra diğer toplumsal ilişkilerinin sağladığı kaynaklar olarak kavramlaştırılan sosyal desteğin, bedensel sağlık ve kendini iyi hissetme üzerinde etkili olduğu vurgulanmaktadır. Yakın çevreden gelecek bu destek, kişinin sağlığı ve uyum süreci üstünde önemli bir etkiye sahiptir (Güni, 2005; Sorias, 1989; Şahin, 1990). Ameliyat, insanların sosyal, psikolojik ve fiziksel yaşamları açısından strese yol açan bir olaydır. Bireyin çevresinden göreceği destekle bu etki hafiflemekte, iyileşmesi olumlu yönde etkilenmektedir. Bir çalışmaya göre başka insanlarla iyi bir bağlantıya sahip olan insanlar, ameliyattan sonraki beş günde düşük endişe, hafif rahatsızlık ve ağrı yaşamaktadır, başka bir deyişle ameliyattan sonra iyi bir iyileşme gösterme ihtimalleri daha yüksektir (Mitchison ve ark., 2008). Pek çok kadın histerektomi ameliyatını kendine olan saygısını yitirme gibi durumlara yol açacak bir girişim şeklinde algılamakta, 
arkadaşları ve ailesinin kendisini reddedeceğinden korkabilmekte, kendine güveni azalabilmekte, bunun sonucunda da depresyon veya sosyal izolasyon yaşayabilmektedir (Banovcinova ve Jandurova, 2018). $\mathrm{Bu}$ yüzden kişi hem ameliyat öncesi hem de ameliyat sonrasında sosyal desteğe ihtiyaç duymakta, korku ve belirsizlik yaşayan bireyler ise daha fazla sosyal desteğe ihtiyaç duymaktadır (Suls, Bunde, Martin ve Barnett, 2006). Histerektomi ameliyatının ardından derlenme sürecinde hastaya fizyolojik ve psikolojik istikrarı ve işlevini tekrar sağlayabilmesi için yardım edilmesi gerekmektedir (Gupta ve Manyonda, 2014: Yakasai, 2013). Histerektomi sonrasında hastalar ne kadar erken iyileşirse, atelektazi ve derin ven trombozu gibi postoperatif komplikasyonlar, gastrointestinal ve abdominal rahatsızlıklar azalacak ve iyileşmenin hızlandırılması sağlanacaktır (Thuy, Thosingha ve Chanruangvanich, 2017). Derlenme kalitesinin artırılması ve derlenme ünitesinde kalınan sürenin azaltılması için, iyileşme süreci boyunca kadınlara işlev ve psikolojik dengenin yeniden sağlanması konusunda yardım edilmesi, derlenme kalitesini artıran ve azaltan faktörlerin tespit edilerek bu doğrultuda bakım planları hazırlanması gerekmektedir (Gupta ve Manyonda, 2014; Thuy, Thosingha ve Chanruangvanich, 2017). Postoperatif derlenmenin kalitesinin arttırılmasında hastaya yapılacak hemşirelik bakımı büyük öneme sahiptir. $\mathrm{Bu}$ doğrultuda histerektomi ameliyatı geçiren kadınlarda derlenme kalitesini hangi unsurların etkilediğinin belirlemesi, hemşirelerin bakımda ele alınması gereken konuların saptamasında ve çözüm yolları geliştirmesinde yol gösterici olacaktır.

$\mathrm{Bu}$ araştırmanın amacı histerektomi ameliyatı geçiren kadınlarda kaygı, ağrı ve sosyal desteğin derlenme kalitesi üzerindeki etkisini incelemektir.

\section{GEREÇ VE YÖNTEM}

\section{Araştırmanın tipi}

$\mathrm{Bu}$ araştırma tanımlayıcı ve kesitsel olarak yapılmıştır.

\section{Araştırmanın evreni ve örneklemi}

Araştırmanın evrenini, bir Üniversitenin Eğitim ve Araştırma Hastanesi Kadın Hastalıkları ve Doğum Kliniğinde bir yılda histerektomi ameliyatı olan 187 kişi oluşturmuştur. Örneklemini ise Evreni bilinen örneklem yöntemi ile \%95 güven aralığında 126 kişinin örnekleme alınması gerektiği hesaplanmıştır, Mart 2019-Ekim 2019 tarihleri arasında histerektomi ameliyatı olan 150 kadın bu araştırmanın örneklem grubunu oluşturmuştur.

Araştırmanın Hipotezleri

$\mathbf{H}_{1}$ : Histerektomi ameliyatı geçiren kadınlarda sürekli kaygının derlenme kalitesi üzerinde etkisi vardır.

$\mathbf{H}_{1}$ : Histerektomi ameliyatı geçiren kadınlarda durumluk kaygının derlenme kalitesi üzerinde etkisi vardir.

H1: Histerektomi ameliyatı geçiren kadınlarda postoperatif ağrı düzeyinin derlenme kalitesi üzerinde etkisi vardır.
$\mathbf{H}_{1}$ : Histerektomi ameliyatı geçiren kadınlarda sosyal desteğin derlenme kalitesi üzerinde etkisi vardır.

\section{Veri toplama araçarı}

Araştırma verilerinin toplanmasında hastaların demografik özellikleri, jinekolojik özellikleri ve hastane deneyimlerini içeren sorulardan oluşan Birey Tanılama Formu, Görsel Kiyaslama Ölçeği-GKÖ (Visual Analog Scale-VAS), Spielberger DurumlukSüreklilik Kaygı Ölçeği (STAI), Algılanan Sosyal Destek Ölçeği ve Derlenme Kalitesi Anketi (Quality Of Recovery-40 Questionnaire [QoR-40]) kullanılmıştır.

Görsel Kıyaslama Ölçeği (GKÖ): Ameliyat sonrası ağrı tedavisi derlenmenin en önemli bileşenidir. Görsel Kıyaslama Ölçeği (GKÖ) ile hastanın ağrı şiddetini subjektif olarak nasıl değerlendiği ölçülebilir. Yatay veya dikey olarak $10 \mathrm{~cm}$ uzunluğunda çizgi çekilir ve çizginin sol ucunda ağrı yok, diğer ucunda ise olabilecek en şiddetli ağrı ifadesi vardır. Hastalardan kendi sağlık durumlarını bu ölçek üzerinde ağrısının şiddetine uygun gördüğü herhangi bir yeri işaret ile belirtmesi istenir (Eti, 2002). Bu araștırmada histerektomi ameliyatı sonrası 24. saatte hastaların ağrı şiddetini değerlendirmek için yatay olarak hazırlanmış GKÖ kullanılmıştır.

Spielberger Durumluk-Sürekli Kaygl Envanteri: Durumluk-süreklilik kaygı ölçeği kısa ifadelerden oluşan bir öz değerlendirme anketidir. Spielberger tarafindan geliştirilen bu ölçeğin Türkiye için geçerliliği ve güvenirliği Öner ve Le Compte tarafından yapılmıştır. Ölçek; Durumluk Kaygi Ölçeği ve Sürekli Kaygı Ölçeği olmak üzere kaygının iki boyutunu ölçmektedir. Durumluk Kaygı Ölçeği, bireylerin belirli bir anda belirli koşullarda kendisini nasıl hissettiğini, içinde bulunduğu duruma ilişkin duygularını betimleyen 20 madde, Sürekli Kaygı Ölçeği ise; bireyin genellikle kendisini nasıl hissetmesi gerektiğini betimleyen 20 madde olmak üzere ölçek toplamda 40 tane dörtlü likert tipi sorudan oluşur. Ölçekte doğrudan ve tersine çevrilmiş ifadeler vardır. Durumluk Kaygı Ölçeğinde 10 tane, Sürekli Kayg1 ölçeğinde ise 7 tane tersine çevrilmiş ifade vardır. Durumluk Kaygı Envanterindeki tersine çevrilmiş ifadeler $1,2,5,8,10,11,15,16,19$ ve 20 . maddelerdir. Sürekli Kaygı Envanterindeki tersine çevrilmiş ifadeler ise 21,26,27,30,33,36 ve 39 uncu maddelerdir. Her iki ölçekten elde edilebilecek toplam puan 20 ile 80 arasındadır. Büyük puan yüksek kaygı, küçük puan ise düşük kayg1 göstergesidir. Ölçeğin güvenirliği "Sürekli Kayg1 Ölçeği” için 0.83 ile 0.87 arasında; "Durumluk Kayg1 Ölçeği” için 0.94 ile 0.96 arasındadır (Öner ve Le Compte, 1983). Bu araştırmada histerektomi ameliyatı geçiren kadınlara ameliyat sonrası 24. saatte Spielberger DurumlukSürekli Kaygı Envanteri uygulanmış, Cronbach Alfa değerleri Durumluluk Kayg1 için 0.91 ve Sürekli Kaygı için 0.85 bulunmuştur.

Çok Boyutlu Algılanan Sosyal Destek Ölçeği: Zimet ve arkadaşları tarafından 1988'de geliştirilen, Türkçe geçerlik güvenirliği ilk olarak 1995 yılında Eker ve 
arkadaşları tarafından yapılan bir ölçektir. Ölçeğin gözden geçirilmiş formunun geçerlilik ve güvenilirlik çalışması, Eker ve arkadaşları (2001) tarafından tekrar yapılmıştır. Ölçek, 12 madde ve üç alt boyuttan oluşmaktadır. Yedili Likert tipi bir ölçektir. Uygulayıcı katılmadığı cümleye en az 1 , katıldığı cümleye de en fazla 7 puan verebilmektedir. Her bir maddeye verilen puan arttıkça algılanan sosyal destek de artmaktadır. Her alt boyutta dört madde puanları toplanarak, alt boyut puanı ve bütün alt boyut puanlarının toplanmasıyla da ölçeğin toplam puanı ortaya çıkmaktadır. Alt ölçeklerden alınabilecek en düşük puan 4, en yüksek puan 28'dir. Ortaya çıkan puanın yüksek olması algılanan sosyal desteğin yüksek olduğunu göstermektedir. Ölçeğin tamamından elde edilecek en düşük puan 12, en yüksek puan 84'tür. Ölçeğin ve alt boyutların güvenilirlik puanları, toplam:0.89, aile:0.85, arkadaş:0.88, özel bir insan:0.92 şeklindedir (Eker ve ark., 2001). Bu araştırmada histerektomi ameliyatı geçiren kadınlara ameliyat sonrası 24. saatte Çok Boyutlu Algılanan Sosyal Destek Ölçeği'nin Cronbach Alfa değerleri aile desteği için 0.76 , arkadaş desteği için 0.72 , özel bir insan desteği için ve ölçek geneli için 0.88 bulunmuştur.

Derlenme Kalitesi Anketi: Derlenme Kalitesi-40 Anketi anestezi ve cerrahi sonrasi derlenme kalitesini ölçmeye yönelik Myles ve arkadaşları tarafından 2000 yılında geliştirilmiş 40 soruluk geniş kapsamlı bir ölçek olup (Myles ve ark., 2000); Karaman ve arkadaşları tarafından da 2014 yılında Türkçe geçerlik ve güvenirliği yapılmış olan derlenme kalitesinin evrensel bir ölçümüdür (Karaman ve ark., 2014).

Derlenme Kalitesi-40; duygusal durum ile ilgili 9 soru, fiziksel konfor ile ilgili 12 soru, hasta desteği ile ilgili 7 soru, fiziksel bağımsızlık ile ilgili 5 soru ve ağrı ile ilgili 7 soru olmak üzere beş alt boyuttan oluşmaktadır. Kısım A ve kısım B olarak ikiye ayrılmıştır. Kısım A'da son 24 saat içerisinde nasıl hissettiği ele alınır ve her öğeye cevap istenir, kısım B'de ise son 24 saat içerisinde belirli fiziksel ya da duygusal belirtilerin varlığı sorgulanır. Sorular 1-5 puan arasında değişen likert ölçeği kullanılarak değerlendirilmektedir. Alt boyut puanları ilgili maddelerin toplanması, toplam puan ise tüm maddelerin toplanmasıyla elde edilir. Puan aralığı; minimum 40 (oldukça zayıf derlenme kalitesi) ve maksimum 200 (mükemmel derlenme kalitesi) arasında değişmektedir. Puan artıkça derlenme kalitesi artmaktadır (Karaman ve ark., 2014). Karaman ve arkadaşlarının (2014) çalışmasında, Derlenme Kalitesi Anketinin iç tutarlılığı değerlendirildiğinde, Cronbach alfa katsayısı ölçek alt boyutları için 0.70 ile 0.95 arasında bulunmuştur (Karaman ve ark., 2014). Bu araştırmada histerektomi ameliyatı geçiren kadınlara ameliyat sonrası 24 . saatte Derlenme Kalitesi-40 Anketi uygulanmıştır. Bu çalışmada ölçeğin Cronbach Alfa değerleri rahatlık için 0.87 , duygu için 0.81 , bağımsızlık için 0.84 , destek için 0.82 , ağrı için 0.74 ve ölçek geneli için 0.92 bulunmuştur.

\section{Veri toplama yöntemi}

Veriler histerektomi ameliyatı sonrası 24. saatte kadın hastalıkları ve doğum kliniklerinde yüz-yüze görüşme yöntemiyle toplanmıştır.

\section{İstatistiksel analiz}

Araştırma verilerinin değerlendirilmesinde SPSS 22.0 programı kullanılarak, tanımlayıcı analizlere yönelik sayı-yüzde ve ortalama dağılımları verilmiştir. Değişkenlerin normal dağılıma uygunluğu görsel (histogram ve olasılık grafikleri) ve analitik yöntemlerle (Shapiro-Wilk testi) incelenmiş ve parametrik şartların sağlandığı görülmüştür. $\mathrm{Bu}$ kapsamda ölçekler arasındaki ilişkilerin değerlendirilmesi için Pearson korelasyon analizi ve multivarite analizleri için Linear regresyon analizi yapılmıştır. Anlamlılık düzeyi $\mathrm{p}<0.05$ düzeyinde kabul edilmiştir.

\section{Araştırmanın etik yönü}

Araştırmanın yapılabilmesi için bir Üniversitenin Girişimsel Olmayan Klinik Araştırmalar Etik Kurulu (Karar no:85, tarih 20.02.2019) ve araştırma yapılacak hastanenin yönetiminden (sayı:47104536-799) gerekli yasal izinler alınmıştır. Araştırmada kullanılan Çok Boyutlu Algılanan Sosyal Destek Ölçeği'nin Gözden Geçirilmiş Formu'nun Türkçe geçerlik ve güvenirliğini yapan H. Arkar'dan, Derlenme Kalitesi40 Anketi'nin Türkçe geçerlik ve güvenirliğini yapan S. Karaman'dan gerekli izinler alınmıştır. Ayrıca araştırma öncesi histerektomi ameliyatı olan kadınlara araştırma hakkında bilgi verilerek araştırmaya katılmaya gönüllü olanlardan sözlü onamları alınmıştır.

\section{BULGULAR}

Hastaların yaş ortalaması $55.13 \pm 11.62$ olup, \%67.3'ü ilköğretim mezunu, \%61.3'ü ev hanımı, \%85.3'ünün geliri giderine denk, \%76.0's1 evli ve \%87.3'ünün ailesi çekirdek aile yapısına sahiptir. Hastaların $\% 49.3$ 'ü bening jinekolojik hastalıklar, \%36.0's1 malign jinekolojik hastalıklar ve \%14.7'si pelvik taban bozuklukları tanılıydı. Hastaların \%64'ü ameliyat öncesinde menopoza girmiştir. Hastaların \%94'ü daha önceden hastanede yatmıştır. Hastaların \%27.3'ü tedavi ve bakımı iyi, \%53.3'ü çok iyi, \%19.3'ü mükemmel olarak değerlendirmiştir. Ayrıca, hastaların \%94.7'si hekim ve hemşirelerin hasta için elinden geleni yaptığını "her zaman" düşünmektedir. Son olarak, hastaların \%40.7'si klinikte alınan bakımdan memnun, \%59.3'ü çok memnundur.

Kayg1 ölçeği puan ortalamaları incelendiğinde; durumluk kaygı ölçeği puan ortalaması 44.10 \pm 10.62 , sürekli kaygı ölçeği puan ortalaması 37.62 7.96 olarak bulunmuştur. Hastaların ağrı şiddetini değerlendirmek amacı ile kullanılan Görsel Kıyaslama ölçeği puan ortalaması $5.52 \pm 1.20$ olarak saptanmıştır. Çok Boyutlu Algılanan Sosyal Destek Ölçeği puan ortalamaları ise, aile desteği alt ölçeği $26.75 \pm 3.23$, özel bir insan desteği alt ölçeği 24.12 \pm 4.76 , arkadaş desteği alt ölçeği $22.46 \pm 6.48$ ve genel ölçek puan ortalaması $73.33 \pm 10.60$ olarak saptanmıştır. Derlenme Kalitesi 
Anketi Puan Ortalamaları incelendiğinde, rahatlık faktörü $46.73 \pm 6.71$, duygu faktörü $35.85 \pm 4.91$, bağımsızlı faktörü $17.67 \pm 3.94$, destek faktörü
$33.37 \pm 2.78$, ağrı faktörü $27.74 \pm 3.63$ ve genel ölçek puan ortalaması $161.36 \pm 16.53$ olarak saptanmıştır (Tablo 1).

Tablo 1. Histerektomi ameliyatı olan kadınlarda kaygı, ağrı şiddeti, algılanan sosyal destek ve derlenme kalitesine ilişkin puan ortalamalarının dağılımı.

\begin{tabular}{|c|c|c|c|c|}
\hline & Min. & Max. & $\overline{\mathbf{X}}$ & SS \\
\hline Durumluk kaygı & 21.00 & 68.00 & 44.10 & 10.62 \\
\hline Sürekli kaygı & 22.00 & 54.00 & 37.62 & 7.96 \\
\hline Ăgrı şiddeti & 3.00 & 9.00 & 5.52 & 1.20 \\
\hline Aile desteği & 12.00 & 28.00 & 26.75 & 3.23 \\
\hline Özel bir insan desteği & 7.00 & 28.00 & 24.12 & 4.76 \\
\hline Arkadaş desteği & 4.00 & 28.00 & 22.46 & 6.48 \\
\hline Toplam sosyal destek algısı & 47.00 & 84.00 & 73.33 & 10.60 \\
\hline Rahatlık & 27.00 & 60.00 & 46.73 & 6.71 \\
\hline Duygu & 20.00 & 45.00 & 35.85 & 4.91 \\
\hline Bağımsızlık & 8.00 & 25.00 & 17.67 & 3.94 \\
\hline Destek & 21.00 & 35.00 & 33.37 & 2.78 \\
\hline Ăgrı & 14.00 & 34.00 & 27.74 & 3.63 \\
\hline Toplam derlenme kalitesi & 100.00 & 196.00 & 161.36 & 16.53 \\
\hline
\end{tabular}

Histerektomi ameliyatı olan kadınlarda Derlenme Kalitesi ile diğer ölçekler ve alt grupları arasındaki ilişkiyi belirlemek için Pearson korelasyon analizi yapılmıştır. Toplam Derlenme Kalitesi ile durumluk kaygı düzeyi arasında negatif yönlü ( $r=-0.434, \mathrm{p}<0.01)$, sürekli kayg

arasında negatif yönlü $(-0.413, \mathrm{p}<0.01)$; ağr1 şiddeti ile negatif yönlü $(\mathrm{r}=-0.499, \mathrm{p}<0.01)$; toplam sosyal destek algısı ile pozitif yönlü ilişki olduğu $(r=0.188, p<0.05)$ istatistiksel olarak anlamlı bulunmuştur (Tablo 2).

Tablo 2. Histerektomi ameliyatı olan kadınlarda kaygı, ağrı şiddeti, algılanan sosyal destek ve derlenme kalitesi puan ortalamaları arasındaki ilişkilerin karşılaştırılması.

\begin{tabular}{|c|c|c|c|c|c|c|c|c|c|c|c|c|}
\hline & $\begin{array}{c}\text { Sürekli } \\
\text { Kaygı }\end{array}$ & $\begin{array}{c}\text { Ăgrı } \\
\text { Şiddeti }\end{array}$ & $\begin{array}{c}\text { Aile } \\
\text { Desteği }\end{array}$ & $\begin{array}{l}\text { Özel bir } \\
\text { İnsan } \\
\text { Desteği }\end{array}$ & $\begin{array}{l}\text { Arkadaș } \\
\text { Desteği }\end{array}$ & $\begin{array}{c}\text { Toplam } \\
\text { Sosyal } \\
\text { Destek } \\
\text { Algısı }\end{array}$ & Rahatlık & Duygu & Bağımsızlık & Destek & Ăğrı & $\begin{array}{c}\text { Toplam } \\
\text { Derlenme } \\
\text { Kalitesi }\end{array}$ \\
\hline & $\mathbf{r}$ & $\mathbf{r}$ & $\mathbf{r}$ & $\mathbf{r}$ & $\mathbf{r}$ & $\mathbf{r}$ & $\mathbf{r}$ & $\mathbf{r}$ & $\mathbf{r}$ & $\mathbf{r}$ & $\mathbf{r}$ & $\mathbf{r}$ \\
\hline Durumluk Kaygı & 0.137 & $0.353^{* *}$ & 0.033 & -0.150 & 0.084 & -0.006 & $-0.406^{* *}$ & $-0.642^{* * *}$ & -0.053 & -0.135 & $-0.195^{*}$ & $-0.434^{* *}$ \\
\hline Sürekli Kaygı & & $0.247^{* *}$ & 0.051 & 0.135 & $-0.176^{*}$ & -0.031 & $-0.360^{* *}$ & $-0.344^{* *}$ & $-0.464^{* *}$ & -0.056 & $-0.202^{*}$ & $-0.413^{* *}$ \\
\hline Ağrı Şiddeti & & & -0.016 & -0.101 & -0.107 & -0.116 & $-0.417^{* * *}$ & $-0.462^{* * *}$ & $-0.321^{* *}$ & $-0.176^{*}$ & $-0.395^{* *}$ & $-0.499^{* *}$ \\
\hline Aile Desteği & & & & $0.300^{\text {*** }}$ & 0.082 & $\mathrm{0.490}^{* * *}$ & -0.003 & 0.067 & -0.014 & $0.401^{* * *}$ & -0.086 & 0.064 \\
\hline $\begin{array}{l}\text { Özel bir İnsan } \\
\text { Desteği }\end{array}$ & & & & & $0.397^{* *}$ & $\mathbf{0 . 7 8 4}^{* *}$ & 0.040 & 0.095 & -0.043 & $0.365^{* *}$ & 0.094 & 0.116 \\
\hline Arkadaș Desteği & & & & & & $0.815^{* * *}$ & $0.170^{*}$ & 0.018 & $\mathbf{0 . 3 0 8}^{* * *}$ & 0.135 & 0.088 & $0.190^{*}$ \\
\hline $\begin{array}{l}\text { Toplam Sosyal } \\
\text { Destek AlgıSı }\end{array}$ & & & & & & & 0.121 & 0.074 & $0.165^{*}$ & $0.370^{* *}$ & 0.070 & $0.188^{*}$ \\
\hline Rahatlık & & & & & & & & $0.760^{\text {*** }}$ & $\mathbf{0 . 5 2 8}^{* * *}$ & $0.326^{* * *}$ & $0.471^{\text {*** }}$ & 0.916 ** \\
\hline Duygu & & & & & & & & & $0.400^{* *}$ & $0.347^{* * *}$ & $\mathbf{0 . 3 7 9}^{* * *}$ & $0.843^{\text {** }}$ \\
\hline Bağımsızlık & & & & & & & & & & $0.195^{*}$ & $\mathbf{0 . 2 9 3}^{* *}$ & $0.669^{\text {*** }}$ \\
\hline Destek & & & & & & & & & & & $0.167^{*}$ & $0.487^{\text {*** }}$ \\
\hline Ăgrı & & & & & & & & & & & & $0.621^{* * *}$ \\
\hline
\end{tabular}

Pearson korelasyon $* * \mathrm{p}<0.01$ ve $* \mathrm{p}<0.05$

Histerektomi ameliyatı olan kadınlarda Kaygı, Ağrı ve Algılanan Sosyal Destek ölçekleri ve alt gruplarının Derlenme Kalitesine etkisini belirlemek amacı ile çoklu regresyon analizi yapılarak değerlendirildiğinde; kayg1, ağrı şiddeti ve algılanan sosyal desteğin varyansa katkısının anlamlı olduğu görülmüştür $(F=17.85$; $p<0.05)$. Kayg1, ağrı şiddeti ve algılanan sosyal destek, toplam derlenme kalitesine ait varyansın \%40’ını açıklamaktadır.
Diğer bir ifade ile toplam derlenme kalitesinin \%40'1 kaygı, ağrı şiddeti ve algılanan sosyal desteğe bağlıdır. Bağımsız değişkenlerin her biri ayrı ayrı değerlendirilecek olursa; durumluk kaygı, sürekli kaygı ve ağrı şiddeti düzeyleri negatif yönde etkilemekte olup düzeyler arttıkça toplam derlenme kalitesi düzeyi azalmaktadır $\left(\beta_{1}=-0.30\right.$, $\beta_{2}=-0.28, \beta_{3}=-0.31 ; \mathrm{p}<0.05$ ) (Tablo 3). 
Tablo 3. Histerektomi ameliyatı olan kadınların kaygı, ağrı şiddeti, algılanan sosyal desteğin derlenme kalitesine etkisinin karşılaştırılması.

\begin{tabular}{|c|c|c|c|c|c|c|}
\hline Bağımsız Değişkenler & $\beta$ & $\mathbf{t}$ & $\mathbf{p}$ & $\mathbf{F}$ & Model (p) & $\mathbf{R}^{2}$ \\
\hline Sabit & & 18.10 & 0.00 & \multirow{7}{*}{17.85} & \multirow{7}{*}{0.00} & \multirow{7}{*}{0.40} \\
\hline Durumluk Kaygı & $-0.30^{1}$ & -4.23 & 0.00 & & & \\
\hline Sürekli Kaygı & $-0.28^{2}$ & -4.04 & 0.00 & & & \\
\hline Ağrı Şiddeti & $-0.31^{3}$ & -4.46 & 0.00 & & & \\
\hline Aile Desteği & 0.07 & 1.06 & 0.29 & & & \\
\hline Özel Bir İnsan Desteği & 0.01 & 0.09 & 0.93 & & & \\
\hline Arkadaş Desteği & 0.12 & 1.70 & 0.09 & & & \\
\hline
\end{tabular}

\section{TARTIŞMA}

Histerektomi ameliyatı geçiren kadınlarda kaygı, ağrı ve sosyal desteğin derlenme kalitesi üzerindeki etkisini incelemek amacıyla yapılan çalışmada hastaların postoperatif dönemdeki kaygı düzeylerinin belirlenmesi için Durumluk-Sürekli Kayg1 Envanteri (STAI) kullanılmıştır. Çalışma kapsamında durumluk kaygı puan ortalaması $44.10 \pm 10.62$, sürekli kayg1 puan ortalaması ise $37.62 \pm 7.96$ olarak hesaplanmıştır. Durumluk kaygı düzeyinin sürekli kaygıdan yüksek bulunması beklenen bir sonuçtur ve hastaların histerektomiye ilişkin endişelerinden kaynaklanabileceğini düşündürmektedir. Konu hakkında yapılan çalışmalar incelendiğinde Özdemir (2008) tarafından histerektomi sonrasında yaşama yönelik verilen eğitim ve gevşeme egzersizlerinin kayg düzeyine etkisinin araştırıldığı çalışmada hastaların durumluk kaygı düzeyleri $41.1 \pm 7.8$ ve sürekli kaygı düzeyleri de $44.1 \pm 8.5$ olarak hesaplanmıştır. Avc1 (2015) tarafindan histerektomi uygulanan hastalarda ağrı ve kaygının azaltılmasında refleksolojinin etkinliğinin araştırılması amacıyla yapılan çalışmada durumluk kaygının ortalaması $37.11 \pm 4.42$ olarak hesaplanmıştır. Ergen ve arkadaşları (2019) tarafindan yapılan bir diğer çalışmada da durumluk kaygı düzeyi total laparoskopik histerektomi uygulanan hastalar için $39.62 \pm 5.44$ ve total abdominal histerektomi uygulanan hastalar için 48.81 \pm 5.64 ; sürekli kayg1 düzeyi ise total lapaoroskopik histerektomi uygulanan hastalar için $51.97 \pm 5.84$ ve total abdominal histerektomi uygulanan hastalar için $50.84 \pm 7.13$ olarak hesaplanmıştır. Çalışmalardaki kaygı düzeyleri farklılıklarının yapılan operasyon tekniği, örneklem grubu farklılıkları, veri toplama zamanı gibi durumlardan kaynaklandığ düşünülmektedir. Çalışmada postoperatif dönemdeki ağrı düzeyinin belirlenebilmesi için Görsel Kıyaslama Ölçeği kullanılmış ve ağrı şiddetinin ortalaması $5.52 \pm 1.20$ olarak bulunmuştur. Utli (2018) tarafindan abdominal histerektomi ameliyatı geçiren kadınlarda reiki ve sırt masajının ağrı üzerine etkisi incelenmiş ağrı düzeyi; reiki uygulanan grupta $6.38 \pm 0.49$, sirt masaj1 uygulanan grupta $6.79 \pm 0.48$ ve kontrol grubunda $6.91 \pm 0.29$ olarak bulunmuştur. Choi ve arkadaşları (2012) tarafından yapılan bir diğer çalışmada ise hastaların histerektomiden bir gün sonraki ağrı düzeyleri total laparoskopik histerektomi uygulanan grup için $3.9 \pm 0.8$ ve vajinal histerektomi uygulanan grup için 4.2 \pm 0.8 olarak tespit edilmiştir. Terzi ve arkadaşları (2015)'in çalışmasında ise hastaların operasyondan 24 saat sonraki ağrı düzeyleri laparoskopik histerektomi grubunda $3.98 \pm 1.11$ ve abdominal histerektomi grubunda $5.57 \pm 1.02$ olarak hesaplanmıştır. Operasyondan sonra ağrı değerlemesinin yapıldığı zamana bağlı olarak hastaların ağrı algılarının farklılaşması beklenen bir sonuçtur. Bu çalışmada operasyondan 24 saat sonra yapılan ağr değerlendirmesi benzer zaman diliminde ölçüm yapan diğer çalışma bulguları ile örtüşmektedir. Araştırma kapsamına alınan hastaların algıladığı sosyal destek düzeyini belirlemek için Çok Boyutlu Algılanan Sosyal Destek Ölçeği kullanılmış ve aile desteği ortalaması $26.75 \pm 3.23$, özel bir insan desteği ortalaması $24.12 \pm 4.76$, arkadaş desteği ortalaması $22.46 \pm 6.48$, toplam sosyal destek algis1 ortalamas $73.33 \pm 10.60$ olarak bulunmuştur. Elde edilen ortalamalar dikkate alındığında hastaların en çok aileden destek aldığı ve bunu çoğunlukla eşlerin oluşturduğu düşünüldüğünde özel bir insan desteği görülmüştür. Konu hakkında yapılan çalışmalar incelendiğinde Banovcinova ve Jandurova (2018) tarafindan yapılan çalışmada özel bir insan desteğinin ortalaması $24.66 \pm 3.48$ ile en yüksek bulunurken; bunu $23.37 \pm 4.11$ ile aile desteği ve $22.07 \pm 4.21$ ile arkadaş desteği izlemiş̧ir. Aynı çalışmada hastaların en çok hangi gruptan destek beklediği de sorgulanmış ve en fazla destek beklenen kişilerin \%68.7 ile eş ya da partnerler olduğu belirlenmiştir. Çalışma bulguları literatür ile benzerdir. Çalışmanın bir diğer basamağında hastaların derlenme kalitesini değerlendirmek üzere Derlenme Kalitesi Ölçeği kullanılmıştır. Buna göre derlenme kalitesi faktörlerinden rahatlık puan ortalamas1 $46.73 \pm 6.71$, duygu puan ortalaması $35.85 \pm 4.91$, bağımsızlık puan ortalamas1 $17.67 \pm 3.94$, destek puan ortalamas1 $33.37 \pm 2.78$ ve ağr1 puan ortalamas1 $27.74 \pm 3.63$ ve toplam derlenme kalitesi puan ortalaması $161.36 \pm 16.53$ olarak belirlenmiştir. Jovanovic ve arkadaşları (2018) tarafindan abdominal histerektomi olmuş hastalarda aynı ölçekle derlenme kalitesini değerlendirdikleri çalışmada 24. saatteki derlenme kalitesinin 170-175 puan aralığında olduğu tespit edilmiştir. Dunn ve arkadaşları (2018) de omurga cerrahisi geçiren hastalarda aynı ölçekle yaptıkları çalışmada derlenme kalitesi puan ortalaması kadınlar için 154 olarak saptanmıştır. Yılmaz ve Aydın (2013) tarafindan elektif ameliyat yapılan hastalar ile yapılan çalışmada ise rahatlik puan ortalaması $48.07 \pm 10.34$. duygu puan ortalaması $35.30 \pm 3.83$, bağımsızlık puan ortalaması 
14.27 \pm 4.12 , destek puan ortalaması $30.02 \pm 4.67$, ağr puan ortalamas $30.79 \pm 4.64$ ve toplam derlenme kalitesi puan ortalaması $158.45 \pm 20.39$ olarak hesaplanmıştır. Çalışma bulguları diğer çalışma bulguları ile paralellik göstermektedir. Diğer cerrahi girişimlerde olduğu gibi histerektomi uygulanan hastalarda da derlenme kalitesini etkileyen faktörlerden bir tanesi hastaların kayg1 düzeyleridir. Ameliyattan sonra yaşanan kayg1, ağrı ve iyileşme temelinde ortaya çıkmaktadır. Ameliyat öncesinde yaşanan kaygının derecesi ise, ameliyattan sonraki ağrıyı arttırmaktadır. Cimilli’ye (2001) göre ameliyattan sonra yüksek düzeyde kaygı yaşayan hastalarda tıbbi komplikasyonlar daha yüksek görülmekte, ağrı tedavi edilmediği zaman ise kaygı düzeyi artmaktadır. $\mathrm{Bu}$ bağlamda bu çalışmada araştırma kapsamına alınan hastaların durumluk ve sürekli kaygılarının derlenme kalitesi ile ilişkisi değerlendirilmiştir. Ulaşılan bulgulara göre durumluk kayg1 ile derlenme kalitesi faktörlerinden rahatlık, duygu ve ağrı arasında negatif yönlü ilişkiler tespit edilmiştir. Toplam derlenme kalitesi açısından bakıldığında da durumluk kaygı ile negatif yönlü ilişkiler tespit edilmiştir. Diğer taraftan sürekli kaygı düzeyi ile rahatlık, duygu, bağımsızlık ve ağrı faktörlerinin yanı sıra toplam derlenme kalitesi arasında negatif yönlü ilişkiler vardır. Regresyon analizi sonuçlarına göre de durumluk ve sürekli kaygının rahatlık ve duygu faktörleri ile birlikte toplam derlenme kalitesini, sürekli kaygının da bağımsızlık faktörünü azalttığı ortaya konulmuştur. Elde edilen bu sonuçlar genel olarak hastaların durumluk ve sürekli kaygılarının olmasının derlenme kalitelerini olumsuz etkileyeceğini göstermektedir. Araştırmanın 1. ve 2. hipotezi desteklenmiştir.

Konu hakkında yapılan çalışmalar incelendiğinde histerektomi uygulanan hastalarda derlenme kalitesi ile kaygı arasındaki ilişkiyi değerlendiren herhangi bir çalışmaya rastlanmamıştır. Ancak diğer cerrahi girişim gruplarında postoperatif kaygının derlenme kalitesini azalttığ1 yönünde bulgular bulunmaktadır. $\mathrm{Bu}$ çalışmalardan Yılmaz ve Aydın (2013) elektif ameliyat uygulanan hastalarda postoperatif dönemde durumluk kaygı ile rahatlık, bağımsızlık ve toplam derlenme kalitesi arasında negatif yönlü ilişkiler olduğunu belirlemiştir. Aynı çalışmada hastaların sürekli kaygı düzeyleri preoperatif dönemde ölçülmüş ve bu ölçümlerin derlenme kalitesi ile ilişkili olmadığı belirlenmiştir. Turhan (2007) tarafından yapılan bir diğer çalışmada Derlenme Kalitesi-40 puanları ile ameliyat öncesi durumluluk kaygı puanları arasında negatif yönde düşük düzeyde ve ameliyat sonrası negatif yönde orta düzeyde bir ilişki olduğu bulunmuştur. Çalışma bulgularının birbirlerini desteklediği söylenebilir.

Histerektomide derlenme kalitesine etkisini araştırdığımız bir diğer faktör ağrıdır. Buna göre ağrı şiddeti ile derlenme kalitesinin tüm faktörleri ve toplam derlenme kalitesi arasında negatif yönlü ilişkiler bulunmaktadır. Bununla birlikte regresyon analizi sonuçları da ağrı şiddetinin rahatlık, duygu, bağımsızlık ve toplam derlenme kalitesini azalttığını ortaya koymuştur. Ulaşılan bu sonuçlar ağrı şiddetinin artmasına bağlı olarak derlenme kalitesinin azalacağını göstermektedir. Çalışmanın 3. hipotezi desteklenmiştir. Abdominal histerektomi ameliyatından sonra \%35-55 oranlarında ağrı hissedilmekte ve iki gün devam etmektedir (Rothaug ve ark., 2013; Y1lmaz ve Gürler, 2011). Ameliyattan sonra şiddetli veya orta şiddette ağrı yaşayan hastalar, ağrı hissetmeyen hastalara oranla hastanede daha fazla kalmaktadır (Xiromeritis ve ark., 2011). Thuy ve arkadaşları (2017) histerektomi uygulanan hastalarda ağrı şiddeti ile derlenme kalitesi arasında negatif yönlü ilişki olduğunu saptamışlardır. Çalışmanın sonucu bu çalışmanın bulgusunu doğrudan desteklemektedir. Çalışma kapsamında histerektomi hastalarında derlenme kalitesini etkileyen bir diğer faktör olarak algılanan sosyal destek değerlendirilmiştir. Çalışma bulgularına göre aile desteği ve özel bir insan desteğinin derlenme kalitesinin destek faktörü ile; arkadaş desteğinin rahatlık, bağımsızlık ve toplam derlenme kalitesi ile; algilanan toplam desteğin de bağımsızlık, destek ve toplam derlenme kalitesi ile düşük düzeyde pozitif yönde ilişkiye sahip olduğu belirlenmiştir. Bununla birlikte yapılan regresyon analizlerinde arkadaş desteğinin bağımsızlı̆̆ özel bir insan desteğinin ise derlenme kalitesinin destek faktörünü arttırdığı belirlenmiştir. Elde edilen bu sonuçlar hastaların aile, eş, partner ya da arkadaştan algıladığ 1 sosyal destek seviyesinin artmasına bağlı olarak derlenme kalitelerinin de yükseleceğini göstermektedir. Çalışmanın 4. hipotezi desteklenmiştir. Konu hakkında yapılan çalışmalar incelendiğinde Banovcinova ve Jandurova (2018)'in histerektomi uygulanan kadınlarda algılanan sosyal destek ile yaşam kalitesi arasındaki ilişki değerlendirilmiştir. Çalışmada aile desteği ile mental sağlik ve zindelik, arkadaş desteği ve toplam sosyal destek algısı ile mental sağlık arasında pozitif yönlü ilişkiler bulunmuştur. Çalışmanın bulgusundan farklı olarak, Thuy ve arkadaşları (2017) total histerektomi uygulanan hastalarda algilanan sosyal destek ile derlenme kalitesi arasında anlamlı ilişki bulamamıştır, bu çalışmada düşük düzeyde de olsa sosyal destek ve derlenme kalitesi arasında pozitif yönlü anlamlı ilişki bulunmuştur.

\section{SONUC}

$\mathrm{Bu}$ çalışma histerektomi ameliyatı olan kadınların ameliyattan 24 saat sonra kayg1, ağrı, sosyal destek ve derlenme kalitelerini değerlendirmek amacıyla yapılmış ve özellikle hastaların kaygı ve ağrı düzeylerinin derlenme kalitesine önemli olumsuz etkiye sahip olduğu sosyal desteğin ise düşük düzeyde de olsa olumlu etkiye sahip olduğu sonucuna varılmıştır. Hemşireler, hastayla devamlı iletişim halinde olan hastaya en yakın sağlık profesyonelleridir. Hemşireler farklı beklentilere, ilgilere, yeteneklere, kişiliğe sahip hastaların yeni hayatlarına uyum sağlama, hastalıği kabullenme ve iyileştirme süreçlerini hızlandırma aşamasında etkin bir role sahiptir. Hemşireler bu bağlamda histerektomi ameliyatı olacak hastaların, ameliyat ya da organ 
kaybıyla ilgili yaşadığı kaygıyı, desteğe ihtiyaç duydukları durumları ayrıntılı bir şekilde değerlendirerek saptamalı ve ameliyat sonrası iyileştirmeyi geciktirebilecek durumların önlenmesi için gerekli girişimlerde bulunmalıdır.

\section{Teșekkür}

Yazarlar bu çalışmaya katkıda bulunan herkese teşekkürlerini sunar.

\section{Çıkar Catıșması}

Yazarlar, bu makalenin araştırılması, yazarlığı ve/veya yayınlanması ile ilgili olarak herhangi bir potansiyel çıkar çatışması beyan etmemiştir.

\section{Yazar Katkıları}

Plan, tasarım: $\mathrm{EB}$, OK; Gereç, yöntem ve veri toplama: $E B$; Analiz ve yorum: $E B$, OK; Yazım ve eleştirel değerlendirme: $\mathrm{EB}, \mathrm{OK}$.

\section{KAYNAKLAR}

Agrawal, S., Chen, L., Tergas, A. I., Hou, J.Y., St.Clair, C.M., Anath, C.V. ... \& Wright, J.D. (2018). Characteristics associated with prolonged length of stay after hysterectomy for benign gynecologic conditions. Am J Obstet Gynecol, 219(1), 89.e115. https://10.1016/j.ajog.2018.05.001.

Avcı, N. (2015). Total Abdominal histerektomi ameliyatı sonrası ağrının ve anksiyetenin azaltılmasinda refleksolojinin etkisi. (Doktora Tezi). İstanbul Üniversitesi, Sağlık Bilimleri Enstitüsü, İstanbul

Bailey, L. (2010). Strategies for decreasing patient anxiety in the perioperative setting. AORN Journal, 92(4), 445460. https://doi.org/10.1016/j.aorn.2010.04.017

Banovcinova, L., \& Jandurova, S. (2018). Subjective perceptions of life among women after hysterectomy. SHS Web of Conferences, 51, 02009. https://doi.org/10.1051/shsconf/20185102009

Choi, K. J., Kim, H. B., \& Park, S. H. (2012). The comparison of postoperative pain: total laparoscopic hysterectomy versus vaginal hysterectomy. Korean Journal of Obstetrics \& Gynecology, 55(6), 384391. https://doi.org/10.5468/KJOG.2012.55.6.384

Cimilli. C. (2001). Cerrahide anksiyete. Klinik Psikiyatri Dergisi, 4 (3), 182-186.

Dunn, L.K., Durieux, M.E., Fernández, L.G., Tsang, S., Smith-Straesser, E.E., Jhaveri, H.F., ...\& Naik, B.I.(2018). Influence of catastrophizing, anxiety, and depression on in-hospital opioid consumption, pain, and quality of recovery after adult spine surgery. Neurosurg Spine, 28(1),119-126. https://doi.org/10.3171/2017.5.SPINE1734

Eker, D., Arkar, H., \& Yaldiz, H. (2001). Çok boyutlu algilanan sosyal destek ölçeğinin gözden geçirilmis formunun faktör yapısı, geçerlik ve güvenirliği. Türk Psikiyatri Dergisi, 12(1), 17-25.

Erdoğan, E., Demir, S., Çalışkan, B. B., \& Bayrak, N. G. (2020). Effect of psychological care given to the women who underwent hysterectomy before and after the surgery on depressive symptoms, anxiety and the body image levels. Journal of Obstetrics and $\begin{array}{lll}\text { Gynaecology, } & \text { 40(7), }\end{array}$ https://doi.org/10.1080/01443615.2019.1678574
Ergen, E. B., Akpak, Y. K., Kılıççı, Ç., Yayla, Ç. A., \& Ayas, S. (2019). Does minimally invasive surgery reduce anxiety?. Journal of the Turkish German Gynecological Association, 20(3), 142-146. https://10.4274/jtgga.galenos.2018.2018.0073

Eti, F. (2002). Ağrı değerlendirme yöntemleri. Cumhuriyet Üniversitesi Hemşirelik Yüksekokulu Dergisi, 6(1), 9-16.

Fong, A. J., Scarapicchia, T. M., McDonough, M. H., Wrosch, C., \& Sabiston, C. M. (2017). Changes in social support predict emotional well-being in breast cancer survivors. Psycho-oncology, 26(5), 664-671. https://10.1002/pon.4064

Gupta, S., \& Manyonda, I. (2014). Hysterectomy for benign gynaecological disease. Gynecology Obstetrics \& Reproductive Medicine, 24(5), 135-140. https://doi.org/10.1016/j.ogrm.2014.04.002

Güler, H., Taşkın, L. (2001). Histerektomi ameliyatı sonrasında ortaya çıkan sorunlarla başetmede planlı eğitimin etkisi. Cumhuriyet Üniversitesi Hemşirelik Yüksekokulu Dergisi, 5(2), 9-19.

Güni, Ö. (2005). Kanserli birey ve ailelerinin sosyal destek algılarının değerlendirilmesi. (Yüksek Lisans Tezi). Hacettepe Üniversitesi, Sosyal Bilgiler Enstitüsü, Ankara.

Hammer, A., Rositch, AF., Kahlert, J., Gravitt, PE., Blaakaer, J., \& Søgaard, M. (2015) Global epidemiology of hysterectomy: possible impact on gynecological cancer rates, American Journal of Obstetrics \& Gynecology, 23-29. http://dx.doi.org/10.1016/j.ajog.2015.02.019

Jovanovic, D., Milovanovic, D. R., Jeremic, N., Nikolic, T., Stojic, Ibir., Jakovljevic, V., \& Vukovic, N. (2019). Oxidative stress parameters after abdominal hysterectomy and their relationships with quality of recovery. Serbian Journal of Experimental and Clinical Research, 20(2), 27-36. http://dx.doi.org/10.1515/sjecr-2017-0046

Karaman, S., Arici, S., Dogru, S., Karaman, T., Tapar H., Kaya Z., ... Balta, M. G. (2014). Validation of the Turkish version of the Quality of Recovery-40 Questionnaire. Health and Quality of Life Outcomes, 12(8), 1-6. http://dx.doi.org/10.1186/1477-7525-128

Mitchison, A. R., Kim, H. M., Geisser, M., Rosenberg, J. M., \& Hinshaw, D. B. (2008). Social connectedness and pain recovery after major operations. Journal of the American College of Surgeons, 206(2), 292-300. http://dx.doi.org/10.1016/j.jamcollsurg.2007.08.017

Myles, P. S., Weitkamp, B., Jones, K., Melick, J., \& Hensen, S. (2000). Validity and reliability of a postoperative quality of recovery score: the QoR-40. British journal of anaesthesia, 84(1), 11-15. doi: 10.1093/oxfordjournals.bja.a013366

Ocalan, R., Akin, C., Disli, Z.K., Kilinc, T., \& Ozlugedik, S. (2015). Preoperative anxiety and postoperative pain in patients undergoing septoplasty. B-ENT, 11(1), 19-23.

Öner, N., \& Compte, A. (1983). Durumluk-Süreklilik Kayg Envanteri el kitabı. İstanbul: Boğaziçi Üniversitesi Matbaas1.

Özbayır T. (2002). Ağrı yönetimi ve hemşirelik bakımı. Ulusal cerrahi kongresi bildiri kitabi içinde (s.131138). İzmir: Ege Üniversitesi Basımevi. 
Özdemir, F. (2008). Histerektomi sonrası yaşama yönelik verilen eğitim ile progresif gevșeme egzersizlerinin anksiyete düzeyine etkisi. (Doktora Tezi). Atatürk Üniversitesi, Sağlık Bilimleri Enstitüsü, Erzurum.

Peterson, J. A. (2000). Nurses providing social support now and in the future. Kansas Nurse, 75(6), 18.

Pinto, P.R., McIntyrec, T., Araújo-Soares, V., Almeida, A., Costa, P. (2018). Psychological factors predict an unfavorable pain trajectory after hysterectomy: a prospective cohort study on chronic postsurgical pain. PAIN, 159(5), 956-967. http://dx.doi.org/10.1097/j.pain.0000000000001170

Preston, N., \& Gregory, M. (2015). Patient recovery and the post-anaesthesia care unit (PACU). Anaesthesia and Intensive Care Medicine, 16(9), 443-445. https://doi.org/10.1016/j.jpain.2013.05.016

Raichle, K.A., Osborne, T.L., Jensen, M.P., Ehde, D.M., Smith, D.G., \& Robinson, L.R. (2015). Preoperative state anxiety, acute postoperative pain, and analgesic use in persons undergoing lower limb amputation. Clin J Pain. 31(8), 699-706. doi: 10.1097/AJP.0000000000000150

Ramdhan, R. C., Loukas, M., Tubbs, R. S. (2017). Anatomical complications of hysterectomy: A review. Clinical Anatomy, 30(7), 946-952. https://doi.org/10.1002/ca.22962

Rothaug, J., Zaslansky, R., Schwenkglenks, M., Komann, M., Allvin, R., Backström, R., ... \& Meissne,W. (2013). Patients' perception of postoperative pain management: Validation of the international pain outcomes (IPO) Questionnaire. J Pain, 14, 13611370. https://doi.org/10.1016/j.jpain.2013.05.016

Shell J., Sittl, R., Griessinger, N., Strupf, M., Parthum, A., Dimova,V.,..\& Lautenbacher, S. (2017). Psychological predictors of acute postoperative pain after hysterectomy for benign causes. Clin J Pain, 33(7), 595-603. https://doi.org/10.1097/AJP.0000000000000442

Sorias, O. (1989). Toplumdan seçilmiş bir örneklemde sosyal ağın yapısal özellikleri ile algılanan sosyal destek, Psikoloji Seminer Dergisi, 7, 27-40.

Stamenkovic DM, Rancic NK, Latas MB, Neskovic V, Rondovic GM, Wu JD, \& Cattano, D. (2018). Preoperative anxiety and implications on postoperative recovery: What can we do to change our history. Minerva Anestesiol, 84, 1307-1317. https://doi.org/10.23736/S0375-9393.18.12520-X

Suls, J., Bunde, M., Martin, R., \& Barnett, K. (2006). Hystersisters online: Social support and social comparison among hysterectomy patients on the internet. Annals of Behavioral Medicine, 31(3), 271. https://doi.org/10.1207/s15324796abm3103_9

Şahin, D. (1990). Sosyal destek ve sağllk. Ankara:Türk Psikologlar Derneği Yayınları.

Terzi, H., Hasdemir, P., Aksu, S., Kale, A., \& Koltan, S. (2015). Comparison of laparoscopic and abdominal methods of hysterectomy from patient's perspective. Medical Science and Discovery, 2(3), 208-210. https://doi.org/10.17546/msd.24068

Thuy, P. T., Thosingha, O., \& Chanruangvanich, W. (2017). Factors related to recovery in patients after total hysterectomy. Journal of Nursing Science, 35(4), $12-20$.

Turhan, Y. (2007). Elektif cerrahi operasyon planlanan hastalarda preoperatif ve postoperatif anksiyetenin hasta memnuniyeti ile ilişkisi. (Uzmanlı Tezi). Çukurova Üniversitesi, Tıp Fakültesi, Adana.
Utli, H. (2018). Abdominal histerektomi ameliyatı geçiren kadınlarda reiki ve sırt masajının ağrı üzerine etkisi. (Doktora Tezi). İnönü Üniversitesi, Sağlık Bilimleri Enstitüsü, Malatya.

Wilson, L. F., Pandeya, N., Byles, J., \& Mishra, G. D. (2019). Hysterectomy status and all cause mortality in a 21 year Australian population-based cohort study. American Journal of Obstetrics and Gynecology, 220(1), $83 \mathrm{e} 1-\mathrm{e} 11$. https://doi.org/10.1016/j.ajog.2018.10.002

Xiromeritis, P., Kalogiannidis, I., Papadopoulos, E., Prapas, N., \& Prapas, Y. (2011). Improved recovery using multimodal perioperative analgesia in minimally invasive myomectomy: a randomized study. Australian and New Zealand Journal of Obstetrics and Gynaecology, 51(4), 301-306. https://doi.org/10.1111/j.1479-828X.2011.01333.x.

Yılmaz, E., \& Aydın, E. (2013). Cerrahi girişim yapılan hastalarda ameliyat öncesi-sonrası anksiyetenin derlenme kalitesine etkisi. Firat Sağllk Hizmetleri Dergisi, 8 (23), 79-95.

Y1lmaz, M., \& Gürler, H. (2011). Hastaların ameliyat sonrası yaşadıkları ağrıya yönelik hemşirelik yaklaşımları: hasta görüşleri. Ăgrl 23(2), 71-79. https://doi.org/10.5505/agri.2011.36349

Zimet, G. D, Dahlem, N. W., Zimet, S. G., \& Farley G.K. (1988). The multidimensional scale of perceived social support. Journal of Personality Assessment, $52,30-41$ 